\title{
A new Tanytarsus species (Insecta, Diptera, Chironomidae) from São Paulo State, Brazil
}

\author{
Susana Trivinho Strixino(1) and Kathia Cristhina Sonoda ${ }^{(2)}$
}

Biota Neotropica v6 (n2)-http://www.biotaneotropica.org.br/v6n2/pt/abstract?article+bn03506022006

\author{
Date Received 24/10/05 \\ Revised: 10/06/06 \\ Accepted: 27/07/06
}

${ }^{1}$ Laboratório de Entomologia Aquática/UFSCar. Caixa Postal 676. CEP 13565-905. Rodovia Washington Luís, Km 235,
São Carlos, SP, Brasil. E-mail: strixino@power.ufscar.br
${ }^{2} \underline{\text { kcsonoda@gmail.com }}$

\begin{abstract}
Strixino, S.T. and Sonoda, K.C. A new Tanytarsus species (Insecta, Diptera, Chironomidae) from São Paulo State, Brazil. Biota Neotrop. May/Aug 2006 vol. 6, no. 2 http://www.biotaneotropica.org.br/v6n2/pt/abstract?article+bn03506022006 ISSN 1676-0603
\end{abstract}

Tanytarsus obiriciae, spec. nov., a new Tanytarsini from the Neotropics is described based on male and female adults, larvae and pupae. The larvae were found living associated with aquatic macrophytes in ponds and lakes from the Northern Region of São Paulo State, Brazil. Information on larval abundance dynamics and the adults' emergence periods is presented.

Key words: Tanytarsus, Neotropical Chironomidae, Brazil, new species.

\section{Resumo}

Strixino, S.T. and Sonoda, K.C. Nova espécie de Tanytarsus (Insecta, Diptera, Chironomidae) do Estado de São Paulo, Brasil. Biota Neotrop. May/Aug 2006 vol. 6, no. 2 http://www.biotaneotropica.org.br/v6n2/pt/ abstract?article+bn03506022006. ISSN 1676-0603

Tanytarsus obiriciae, spec. nov., nova espécie de Tanytarsini da região Neotropical é descrita com base em todos os estágios, macho e fêmea adultos, pupa e larva. As larvas foram encontradas vivendo associadas a macrófitas aquáticas em lagoas e lagos da região norte do Estado de São Paulo, Brasil. Informações sobre a dinâmica numérica das larvas e a periodicidade da emergência dos adultos são apresentadas.

Palavras-chave: Tanytarsus, Chironomidae Neotropical, Brasil, nova espécie. 


\section{Introduction}

Studies on the macroinvertebrate fauna from ponds and reservoirs of the Northern Region of São Paulo State have revealed great abundance of Chironomidae larvae, mainly in areas rich in aquatic macrophytes, where together with Naididae (Oligochaeta) worms were the most abundant group in the phytofauna (Trivinho-Strixino et al. 1998).

The presence of Tanytarsini larvae in the phytofauna has been observed in several of our studies at the Laboratório de Entomologia Aquática at the Universidade Federal de São Carlos (Sonoda 1999; Sonoda \& TrivinhoStrixino 2000; Trivinho-Strixino et al. 2000). The larvae of the new Tanytarsini described here (genus Gen. A sp. 2, cf. Trivinho-Strixino \& Strixino 1995) are commonly found on different macrophytes like Pontederia, Eichhornia, Cabomba, Utricularia and Mayaca, but the association of these larvae to their adult counterparts was not possible until now. In a recent phenological study of Chironomidae associated with Cabomba piauhyensis Gardney, 1844 (Sonoda 1999), it was possible for us to raise some larval specimens to adults, thus making all stages of the new species available for description.

\section{Material and Methods}

The material examined was mounted on slides in Euparal ${ }^{\circledR}$ or Hoyer's medium. The general terminology follows Sæther $(1977,1980)$. The term 'taeniae' is used for the flattened setae on the pupal abdomen in accordance with Langton (1994).

Measurements are given as the value of the holotype (where applicable) followed by the range, in brakets, based on the smallest and largest paratypes, respectively. Seta counts are given as the range only.

The holotype and most paratypes are deposited in the Laboratório de Entomologia Aquática collection, Universidade Federal de São Carlos, São Paulo, Brazil (UFSCar). One male imago, one female and one larva paratypes are deposited on Museu de Zoologia of São Paulo State, São Paulo, Brazil (MZUSP). One male and one larva paratypes are deposited in Zoologische Staatssammlung München, Germany.

\section{Results}

Tanytarsus obiriciae, spec. nov.

Tanytarsini Gênero A sp. 2 Trivinho-Strixino \& Strixino 1995: 189.

Types. Holotype: male imago with associated pupal exuvia, Brazil, São Paulo, LuizAntônio, viii.2003. S. TrivinhoStrixino. Paratypes: 1 adult male with associated pupal exuvia, Brazil, São Paulo, Luiz Antônio, vii.2002. S. TrivinhoStrixino; 2 adult males, 2 larvae, Brazil, São Paulo, Luiz Antônio, viii.1997. K. C. Sonoda; 2 adult males, 6 females and 4 larvae, Brazil, São Paulo, São Carlos, xi.1993. S. Trivinho-Strixino; 1 male with associated pupal exuvia, Brazil, São Paulo, São Carlos, ix.1999. S. Trivinho-Strixino; 1 pupa with pharate male, Brazil, São Paulo, Luiz Antônio xi.1994. S. Trivinho-Strixino 1 male adult, Brazil, São Paulo, Luiz Antônio. v.2003. S. Trivinho-Strixino.

Etymology. The species name is dedicated to a legendary native brazilian indian woman, Obirici, whose tears are said to have formed the Mogi-Guaçu River, one of the biggest rivers of São Paulo State. One of the places where the new species was found, Infernão Lake, belongs to the system formed by the marginal lakes surrounding the MogiGuaçu River.

\section{Description \\ Male imago $(\mathrm{n}=8)$.}

Small, near $2.5 \mathrm{~mm}$ long. Body colour in $70 \%$ ethyl alcohol yellowish brown.

Head: Colour yellowish. Antenna and plume brownish, $844 \mathrm{~mm}$ [ 737 - 1036] long. $\mathrm{AR}=0.81$ [0.62 - 0.87]. Maxillary palp yellowish, length of palpomeres 2-5: 35, 64, 79, 137 $\mathrm{mm}$. Temporal setae 8-9. Clypeus with 8-10 setae.

Thorax: Mesonotum yellowish brown. Scutellum yellowish. Postnotum brownish. Thoracic setal count: $5-8$ acrostichals, $5-7$ dorsocentrals, 1 -2 prealars, 3 - 5 scutellars.

Wing : Length $1.23 \mathrm{~mm}$ [1.20 - 1.38], width $0.38 \mathrm{~mm}$ [0.34-0.42]; transparent with lightly pigmented veins. $\mathrm{VR}=$ 1.26 [1.13 - 1.25]. Membrane with macrotrichia restricted to distal half. Anal lobe reduced. Squama reduced, lacking macrotrichia. Brachiolum with 2 macrotrichia. Macrotrichia present on all veins, except on $\mathrm{M}$ and $\mathrm{Sc}$.

Legs: Colour yellowish brown. Leg segment lengths (in mm) and leg ratios (LR):

\begin{tabular}{rcccccccc}
\hline & $\mathrm{Fe}$ & $\mathrm{Ti}$ & $\mathrm{Ta}_{1}$ & $\mathrm{Ta}_{2}$ & $\mathrm{Ta}_{3}$ & $\mathrm{Ta}_{4}$ & $\mathrm{Ta}_{5}$ & $\mathrm{LR}$ \\
\cline { 2 - 9 } LI & 587 & 250 & 781 & 381 & 319 & 231 & 137 & 3.12 \\
& {$[533-675]$} & {$[204-274]$} & {$[722-894]$} & {$[361-439]$} & {$[282-378]$} & {$[219-286]$} & {$[102-125]$} & \\
\cline { 2 - 10 } LII & 612 & 450 & 326 & 131 & 95 & 61 & 45 & 0.72 \\
& {$[596-675]$} & {$[345-487]$} & {$[314-345]$} & {$[125-157]$} & {$[78-109]$} & {$[47-62]$} & {$[31-55]$} & \\
\cline { 2 - 10 } LIII & 643 & 544 & 480 & 237 & 194 & 126 & 62 & 0.88 \\
& {$[659-722]$} & {$[502-580]$} & {$[486-510]$} & {$[251-266]$} & {$[188-235]$} & {$[125-141]$} & & \\
\hline
\end{tabular}

http://www.biotaneotropica.org.br 
Hypopygium (Fig. 1, 2). Tergite IX with 12-15 posteromedian setae. Anal tergite bands separate. Anal point bare, slender, $23 \mathrm{~mm}$ [20 - 28] long, with distal end slightly broader than proximal, without crests. Superior volsella somewhat rectangular, 60mm [55 - 68] long, with a dorsolateral swelling bearing 2 dorsal and 4 marginal setae. Digitus absent. Inferior volsella digitiform, microtrichiose not folded, bearing 5 long distal and 5 short dorsal setae. Median volsella near $110 \mathrm{~mm}$ long, with numerous long hair-like, distally divided, lamellae (Fig. 3). Transverse sternapodeme narrow not laterally produced. Phallapodeme 63mm [58-65] - Gonostylus 100 mm [93108] long; Gc/Gs $=0.93$ [0.90-0.99].

Female $(\mathrm{n}=5)$.

Body color as male. Body length about $2.3 \mathrm{~mm}$.

Head: Antenna length 298 mm [235 - 376], antennal flagellomeres 2-6: 41, 54, 60, 35, $65 \mathrm{~mm}$. Palpomeres 2-5: 31, $62,73,131 \mathrm{~mm}$. Temporal setae 13. Clypeus with 12-13 setae.

Thoracic setal count: $4-7$ acrostichals, $4-6$ dorsocentrals, 1 prealar, $2-4$ scutellars.

Wing: Length 1.16mm[1.06-1.36]; VR=1.26[1.00-1.44].

Leg segment lengths in $\mathrm{mm}$ and LR proportions: large floor under anterior part of vagina. GpVIII slightly divided with long caudal and caudolateral microtrichia. Notum slithly longer than seminal capsules, and as long as free rami. Seminal capsules ovoid, near $46 \mathrm{~mm}$ long, without neck. Spermathecal duct with loop. Gc IX with 2-3 setae. Post genital plate triangular, as large as long. Cerci long, length near $50 \mathrm{~mm}$.

\section{Pupa $(\mathrm{n}=2)$.}

Exuviae pale. Abdominal length about $3 \mathrm{~mm}$. Frontal apotome with minute cephalic tubercles; Frontal setae elongate (Fig 5). Thoracic horn smooth, near $350 \mathrm{~mm}$ long. Thorax smooth with weak granulation along median anterior suture. Wing sheath with prominent nose, without pearl row. Thoracic setation: on each side 2 precorneals (PC) situated in front of the thoracic horn. Two lateral antepronotals $\left(\mathrm{LAps}_{1-2}\right) .4$ dorsocentrals $\left(\mathrm{DC}_{1-4}\right)$ present and situated in two widely separated pairs; $\mathrm{DC}_{4}$ longer than $\mathrm{DC}_{3}$ (Fig. 6). Abdomen in dorsal aspect as in Fig. 7. Tergite I without shagreen. Tergites II - IV with pair of isolated point patches; VII and VIII without points. Tergite II with shagreen in small area just anterior to hook row. Hook row continuous, occupying about $1 / 3$ width of segment II. Pedes spurii A and B

\begin{tabular}{rcccccccc}
\hline & $\mathrm{Fe}$ & $\mathrm{Ti}$ & $\mathrm{Ta}_{1}$ & $\mathrm{Ta}_{2}$ & $\mathrm{Ta}_{3}$ & $\mathrm{Ta}_{4}$ & $\mathrm{Ta}_{5}$ & $\mathrm{LR}$ \\
\cline { 2 - 8 } LI & 515 & 264 & 672 & 333 & 267 & 201 & 100 & 2.77 \\
& {$[330-660]$} & {$[172-410]$} & {$[565-942]$} & {$[251-440]$} & {$[220-330]$} & {$[125-314]$} & {$[78-141]$} & \\
\cline { 2 - 8 } LII & 487 & 416 & 230 & 105 & 76 & 45 & 45 & 0.54 \\
& {$[392-612]$} & {$[345-502]$} & {$[157-314]$} & {$[78-141]$} & {$[62-94]$} & {$[31-55]$} & {$[31-55]$} & \\
\cline { 2 - 9 } LIII & 515 & 475 & 323 & 175 & 161 & 88 & 56 & 0.67 \\
& {$[408-628]$} & {$[408-612]$} & {$[235-408]$} & {$[141-235]$} & {$[125-235]$} & {$[62-141]$} & {$[47-78]$} & \\
\hline
\end{tabular}

Genitalia (Fig. 4): Sternite VIII bearing 20-23 setae irregularly distributed, on each side. GcaVIII nearly straight, ends on base of dorsomesal lobe of GpVIII. SVIII forms a absent. Posterolateral corner of segment VIII with comb consisting of 5 yellow-brown teeth (Fig. 8). Each anal lobe with 13 taeniae in a single row and 2 dorsal taeniae.

Abdominal setation:

\begin{tabular}{cccc}
\hline Segment & tergite & sternite & lateral \\
\hline I & 4 & 2 & 0 \\
II & 4 & 6 & 3 \\
III & 6 & 6 & 3 \\
IV & 6 & 6 & 3 \\
V & 6 & 6 & 3 \\
VI & 6 & 6 & 3 \\
VII & 6 & 6 & 3 \\
VIII & 2 & 2 & $4 \mathrm{~T}$ \\
\hline
\end{tabular}

http://www.biotaneotropica.org.br 

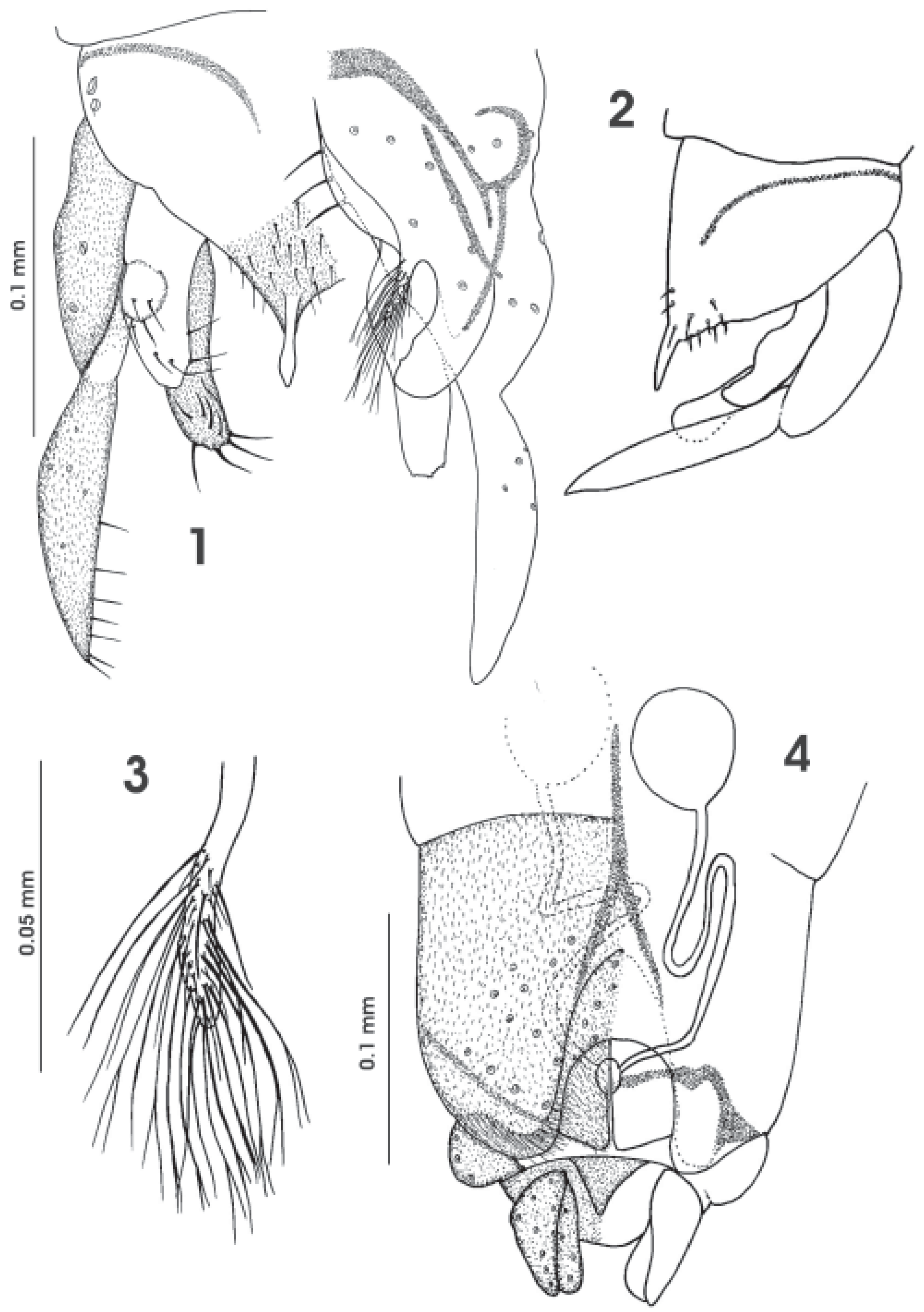

FIGURES 1 - 4. Tanytarsus obiriciae, spec. nov. Male and female. 1: Hypopygium, dorsal view left, ventral view right. 2: Hypopygium, lateral view. 3: Median volsella. 4: Female genitalia, dorsal. 


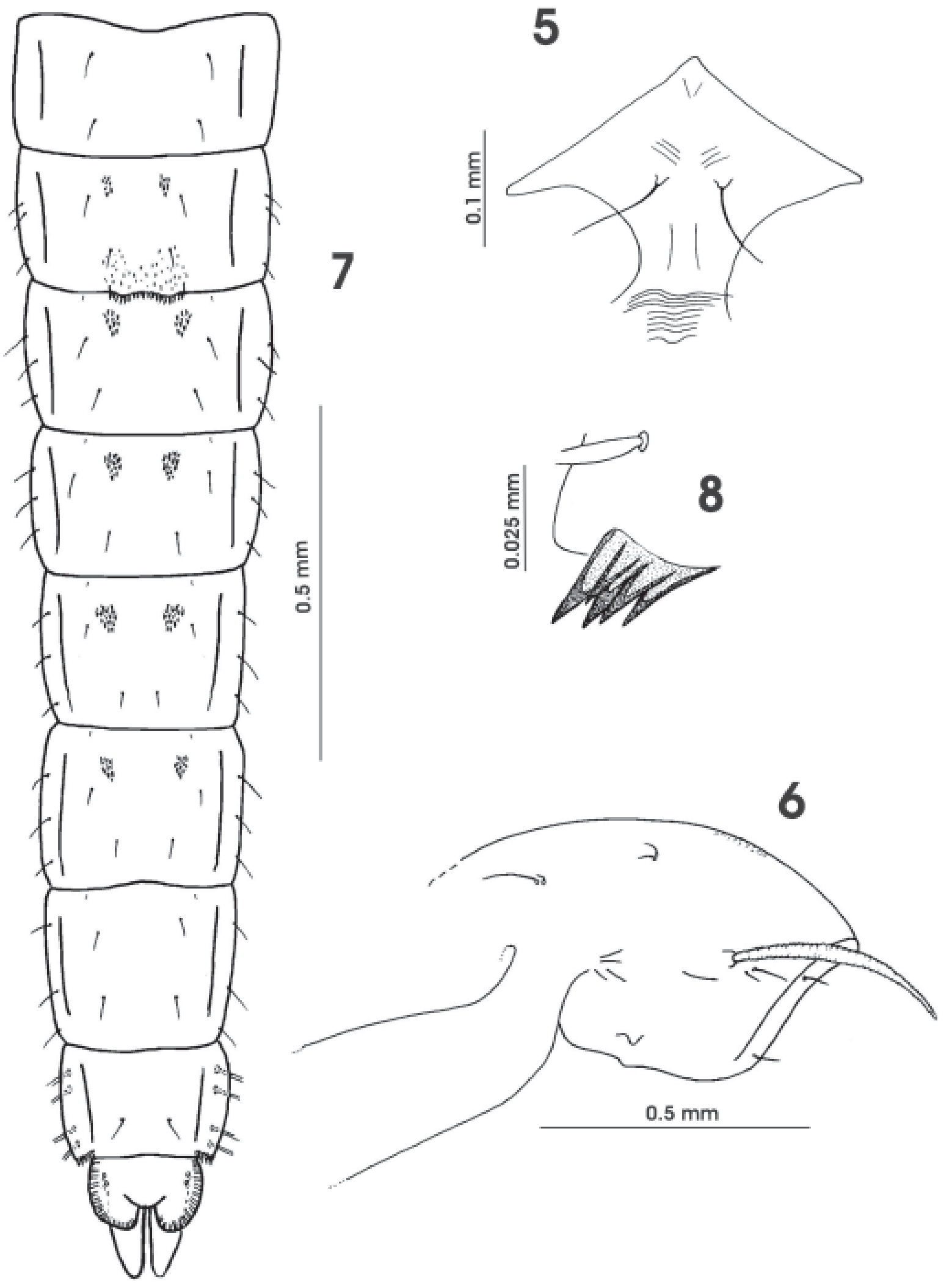

FIGURES 5 - 8. Tanytarsus obiriciae, spec. nov. Pupa. 5: Frontal apotome. 6: Thorax. 7: Abdominal tergites. 8: Posterolateral comb of segment VIII.

http://www.biotaneotropica.org.br 


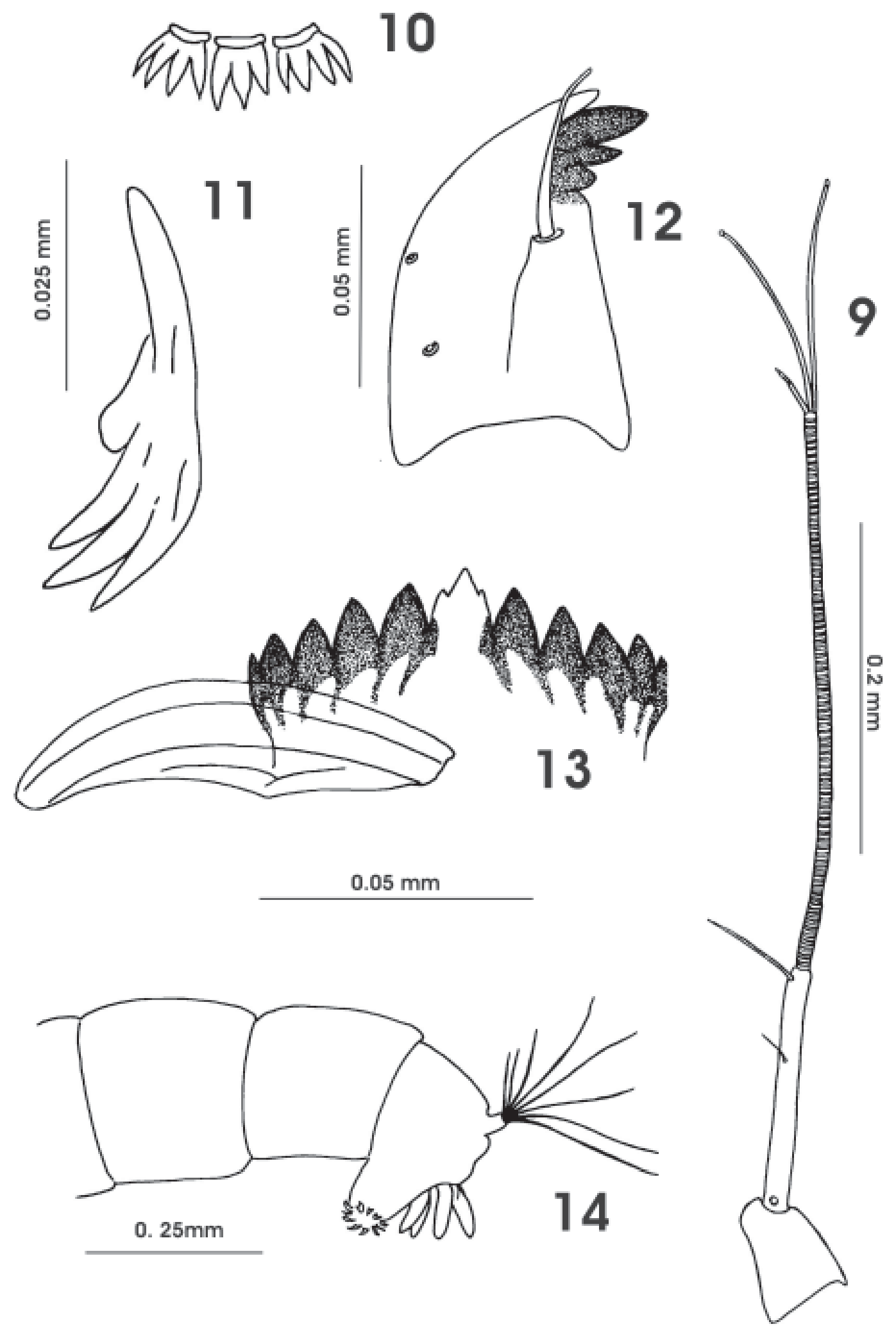

FIGURES 9 - 14. Tanytarsus obiriciae, spec. nov. Larva. 9: Antenna. 10: Pecten epipharyngis. 11: Premandible.12: Mandible. 13: Mentum and ventromental plate. 14: Posterior abdominal segments. 


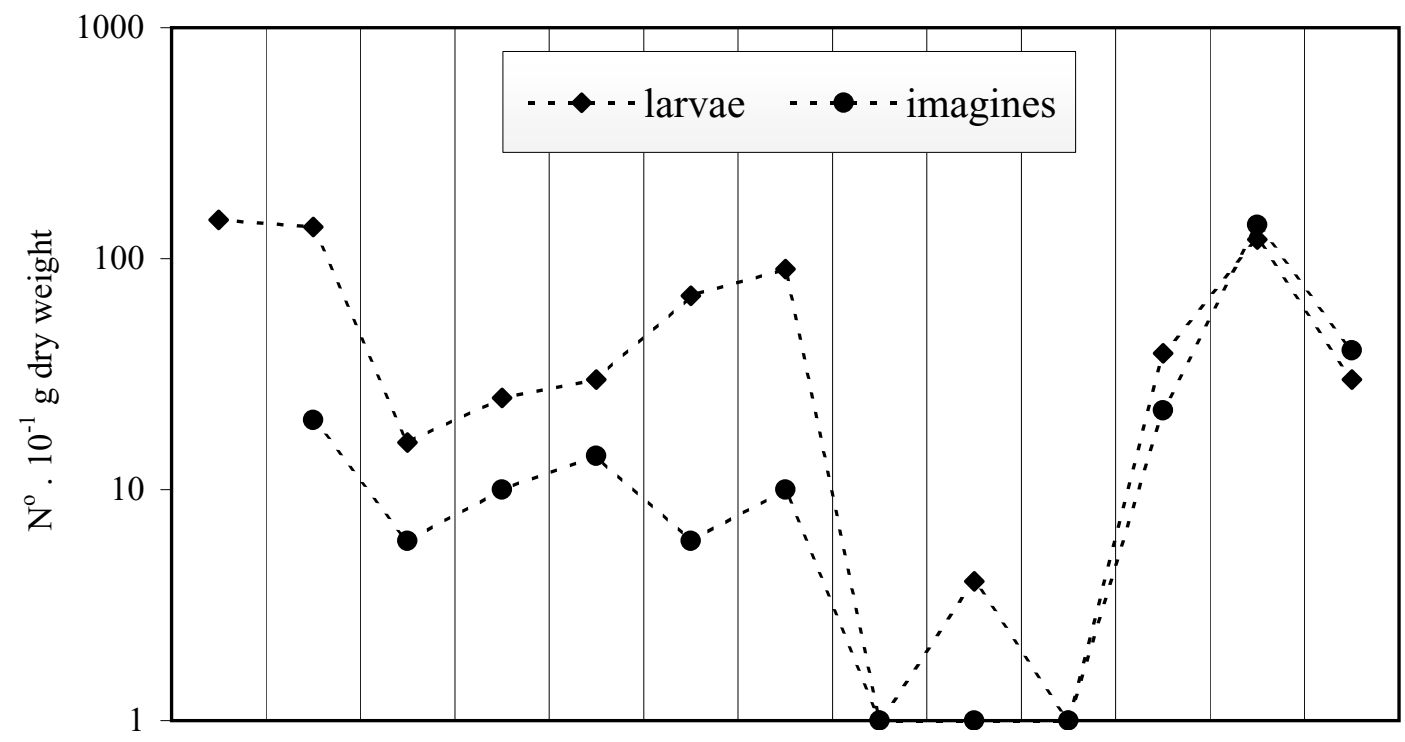

A

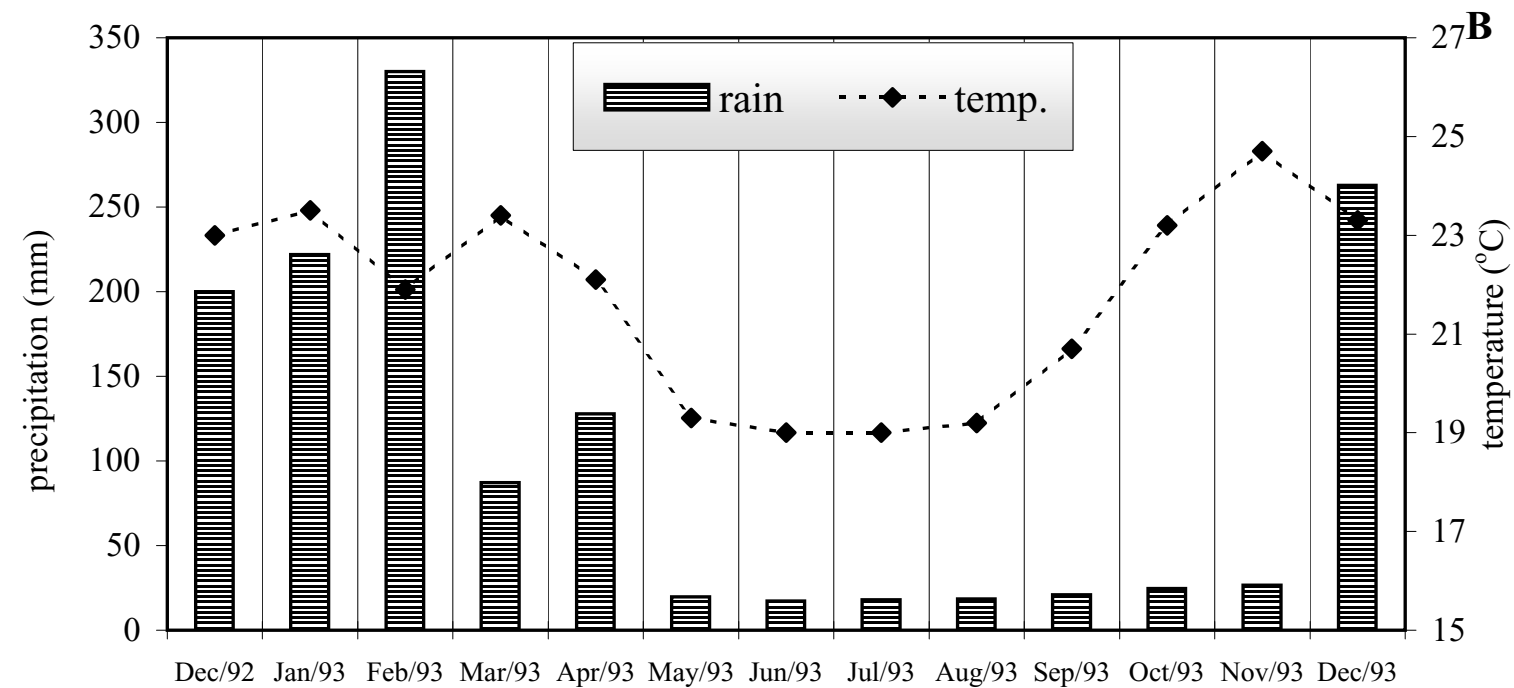

FIGURE 15. A: Abundance of Tanytarsus obiriciae adults and larvae from December 1992 to December 1993 in Mayaca Pond. B: Mean monthly temperature and monthly precipitation from December 1992 to December 1993.

$4^{\text {th }}$ instar larva $(\mathrm{n}=5)$.

Total length: $2.8 \mathrm{~mm}$ [2.2 - 3.7]. Color pale red.

Head: Width $189 \mathrm{~mm}$ [184 - 199], length $264 \mathrm{~mm}$ [245 -275]. Antenna 5-segmented placed on short pedestal, pedestal without apical tooth (Fig. 9); basal segment shorter than flagellum, with basal ring organ and small seta in distal half; $\mathrm{AR}=0.41$ [0.39 - 0.43]; segment II very long $355 \mathrm{~mm}$ [333 - 382], spirally structured in whole length. Lauterborn organs short situated on $113 \mu \mathrm{m}[110-120]$ long pedicels. Pecten epipharyngis (Fig. 10) consists of three indented scales. Premandible (Fig. 11) with three teeth. Mandible (Fig.
12) with pale dorsal tooth; apical and 2 inner teeth brown. Mentum (Fig. 13) with pale median tooth, laterally notched; 5 pairs of light brown lateral teeth regularly decreasing in size. Ventromental plates touching medially.

Anal tubules about $130 \mathrm{~mm}$ long (Fig. 14).

\section{Taxonomic remarks}

Tanytarsus obiriciae, spec. nov. appears closely related to the species of the genus reviewed by Sanseverino (2006), in particular the Neotropical species group in which anal crests are absent and anal tergal bands are not fused (T. reissi Paggi, 1992, T. magnus Trivinho-Strixino \& Strixino, 
2004, T. impar Trivinho-Strixino \& Strixino, 2004 and T. fastigatus Reiss, 1972). The shape of the superior volsella, especially the dorsolateral bulbous structure and the median volsella with long simple and distally divided lamellae are the most distinguishing features that discriminate $T$. obiriciae, spec. nov., from these Neotropical Tanytarsus species. The hypopygium of T. obiriciae is also similar to that of T. breda (Roback 1960) in its general appearance (cf. Roback 1960), but differs from this species by the shape of the superior and median volsellae and by lacking the two long median tergite setae. The larvae exhibit an uncommon characteristic, the very long and annulated antennal segment 2 that distinguishes it from other Tanytarsini. In the Guide to Chironomidae Larvae of São Paulo State (TrivinhoStrixino \& Strixino 1995) this species was called Tanytarsini Gênero A sp.2. The feature is unique among the Tanytarsini, but similar to the annular Lauterborn organs pedicels of the Nimbocera patagonica and some Tanytarsus and Caladomyia species (Trivinho-Strixino \& Strixino 2003; Trivinho-Strixino \& Sanseverino 2003). This characteristic annulation of the second antennal segment of some species of Tanytarsus larvae was commented by authors as Roback (1966) with his Calopsectra sp.13, Nolte (1989) with Tanytarsus (b) and Epler (2001) with Tanytarsus sp. F.

\section{Ecological notes}

The larvae of Tanytarsus obiriciae are characteristic of the phytophylous communities of numerous lentic systems of the Northern Region of São Paulo State. They build long tubes and feed on the fine detritus (FPOM) of the biofilm stuck to the macrophyte walls (Trivinho-Strixino et al. 2000; Correia \& Trivinho-Strixino 1998).

The abundance dynamics of T. obriciae was measured monthly on stands of Mayaca fluviatilis Aublet, 1775 in one little reservoir (Mayaca Pond) at the Universidade Federal de São Carlos Campus (2201' S, 47053' W). From December 1992 to December 1993, the larvae and adults were collected monthly on M. fluviatilis stands in this pond. On this macrophyte, the larvae of T. obiriciae corresponded to approximately $7 \%$ of the total chironomid fauna and showed a mean numeric density of 54 individuals per $10 \mathrm{~g}$ dry weight of $M$. fluviatilis (Fig. 15A). The higher values coincide with periods of higher rainfall and temperature (spring/summer) (Fig. 15B). Adult emergence, monitored in the same period, showed the same dynamic pattern as the larvae with absence of emergence in the winter months (July to September). The seasonal pattern shows the higher values of larvae and adults in rainy months (from December to April). The same pattern was observed when the emergence of $T$. obiriciae was monitored in an oxbow lake (Infernão Lake) in Jataí Ecological Station (Luiz Antônio, SP). In this lake the larvae live associated with the macrophyte C. piauhyensis (Sonoda, 1999). These observations seem to indicate that $T$. obiriciae reproduces continuously along the year and the phenology is not influenced by plant morphology although it is probably controlled by climatic conditions. Adults emerged throughout the whole year, with a small reduction in the winter period, possibly due to the slower development caused by lower temperatures.

\section{Acknowledgements}

We are grateful to Dr. Sebastião José de Oliveira, for the judicious review of the manuscript, his comments and suggestions. To the Coordenadoria de Assistência Técnica Integral (CATI) of the Secretaria da Agricultura e Abastecimento from Luiz Antônio (SP, Brazil), and to Dr. Gilson Pereira de Oliveira from Centro de Pesquisa de Pecuária do Sudeste - CPPSE/CANCHIM- EMBRAPA/São Carlos which gently provided us the climatic data from Luiz Antônio and São Carlos regions.

\section{References}

CORREIA, L.C.S. \& TRIVINHO-STRIXINO, S. 1998. Macroinvertebrados da rizosfera de Scirpus cubensis na Lagoa do Infernão (Estação Ecológica de Jataí - SP): Estrutura e Função. Acta Limnol. 10(1): 37-47.

EPLER, J.H. 2001.Identification manual for the larval Chironomidae (Diptera) of North and South Carolina. North Carolina Department of Environment and Natural Resources Division of Water Quality. 528p.

LANGTON, P.H. 1994. If not "filaments" then what? Chironomus newsletter of Chironomidae research .6: 9.

NOLTE, U. 1989. Observations on Neotropical rainpools (Bolivia) with emphasis on Chironomidae (Diptera). Stud. Neotrop. Fauna Envir. 24:105-120.

ROBACK, S.S. 1960. Results of the Cartherwood Peruvian-Amazon expedition. New species of South America Tendipedidae (Diptera). Trans. Amer. Ent. Soc., 84: 87- 107.

ROBACK, S.S. 1966. Catherwood foundation Peruvian Amazon expedition. XII - Diptera, with some observations on the salivary glands of the Tendipedidae. Acad. Natur. Sci. Philadelphia 14: 305-375.

SAETHER, O.A. 1977. Female genitalia in Chironomidae and other Nematocera: morphology, phylogeny, keys. Bull. Fish. Res. Board. Can. 197: 1-209.

SAETHER, O.A. 1980. Glossary of chironomid morphology terminology (Diptera: Chironomidae). Ent. Scand. Suppl. 14:1-51.

SANSEVERINO, A.M. 2006. A review of the genus Tanytarsus van der Wulp, 1874 (Insecta, Diptera, Chironomidae) from the Neotropical region. Disserttation zur Erlangung des Doktorgrades der Fakultät für Biologie der Ludwig-Maximiliams-Universität München, München, 307 p. 
SONODA, K.C. 1999. Chironomidae (Diptera) da fitofauna de Cabomba piauhyensis Gardney, 1844. Dissertação de mestrado. Universidade Federal de São Carlos, São Carlos, $60 \mathrm{p}$.

SONODA, K.C.\& TRIVINHO-STRIXINO, S. 2000. Dinâmica da emergência de Chironomidae (Díptera) da fitofauna de Cabomba piauhyensis Gardney, 1844, na Lagoa do Infernão (Estação Ecológica de Jataí, Luiz Antônio, SP). In Estação Ecológica de Jataí (J. E. Santos \& J. S. R. Pires, eds.) RiMa Editora, São Carlos, v.2, p.743-754.

TRIVINHO-STRIXINO, S. \& STRIXINO, G. 1995. Larvas de Chironomidae do Estado de São Paulo. Guia de identificação e diagnose dos gêneros. São Carlos: PPGERN/UFSCAR, 229p. IL., estampas.

TRIVINHO-STRIXINO, S. \& STRIXINO, G. 2003. The immature stages of two Caladomyia Sawedall, 1981 species, from São Paulo State, Brazil (Chironomidae, Chironominae, Tanytarsisni). Rev. Bras. Ent., v.47, pars 4, p.597-602.

TRIVINHO-STRIXINO, S.; GESSNER,A. F. \& CORREIA, L. 1998. Macroinvertebrados associados a macrófitas aquáticas das lagoas marginais da Reserva Ecológica de Jataí (Luiz Antônio-SP). Anais VIII Semin. Reg. Ecol.PPG-ERN/UFSCar. v. III, p.1189-1198.

TRIVINHO-STRIXINO, S.; CORREIA, L. C. \& SONODA, K. C. 2000. Phytophilous Chironomidae (Diptera) and other macroinvertebrates in the ox-bow Infernão Lake (Jataí Ecological Station, Luiz Antônio, SP, Brazil). Rev. Bras. Biol. v.60, pars 3, p.527-535.

TRIVINHO-STRIXINO, S. \& SANSEVERINO, A. M., 2003. Tanytarsus rhabdomantis: new combination for Nimbocera rhabdomantis Trivinho-Strixino \& Strixino, 1991 (Diptera: Chironomidae). Zootaxa, v.389, p.1-10.
Title: A new Tanytarsus species (Insecta, Diptera, Chironomidae) from São Paulo State, Brazil

Authors: Strixino, S.T. and Sonoda, K.C.

Biota Neotropica, Vol. 6 ( number 2): 2006

$\mathrm{http}: / / \mathrm{www} \cdot$ biotaneotropica.org.br/v6n2/pt/ abstract?article+bn03506022006

Date Received: 24/10/05

Revised: 10/06/06

Accepted: 27/07/06

ISSN 1676-0611 